Some of these features are characteristic of desert-plants. Many desert -plants have reduced transpiring surfaces and hidden stomates. They often have very long roots, as was particularly observed in the excavations for the Suez canal. ${ }^{1}$ 'The leaves are often small and crowded, the stems woody, much branched and tufted. Bright sunlight retardis growth, and green tissues hardly ever present a large absorbing surface when they are habitually exposed to bright light. Accordingly the young shoots and branches do not push out freely, but try to hide one behind another. The tissues of desert-plants may be remarkably dry ; they are often, however, remarkably succulent ; the plant either learns to do without water for a long time together, or to store it up.

It is not without surprise that we learn how similar are the effects of tropical drought and of Arctic cold. The facts of distribution would in themselves suffice to show that our moorland heaths are well-fitted to endure great cold. Ling extends far within the Arctic circle, though it seldom covers large surfaces there, and it rises to 2000 metres $(6600$ feet) on the north side of the Alps It extends southward to the shores of the Mediterranean. Our large-flowered heaths have not been traced quite so far north as ling, and they are not found on the Alps, though they inhabit the Pyrenees. Many representatives of the heath family, with like structure of leaves, are found in the extreme north of the American continent. Those features which assimilate our heaths to desert-plants, and which seem to be obvious adaptations to a situation of extreme drought, are equally serviceable to plants which have to face boisterous winds and low temperature. The shrubs of the far north are low, tufted, small-leaved, evergreen, and dry-just like the heaths of our moors. Middlendorff ${ }^{2}$ shows how the I)ahurian larch becomes stunted in proportion to increasing cold. Before it disappears altogether, it is cut down to a prostrate, creeping shrub. One such dwarf larch, though I 50 years old, was only a foot or two across. Plants much exposer? to biting winds must make the most of any shelter that can be had; their branches push out timidly, and for a very short distance; the leaf-surface is reduced to a minimum : since the warm season is short, evergreen leaves are profitable, for they enable the plants to take advantage of early and late sunshine.

The heaths and many other moorland plants bear the marks of the Xerophy'es, or drought-plants. Xerophytes grow under a considerable varicty of conditions, some of which do not suggest drought at first sight, but their tissues are always ill-supplied with water. It may be that water is not to be had at all, as in the desert; or that water must not be imbibed in any quantity because of low temperature, as in Arctic and Alpine climates; or that the water is mixed with useless and perhaps injurious salts, from which it can only be separated with great difficulty, as in a salt-marsh. Whatever may be the reason for abstinence, xerophytes absorb water slowly, part with it slowly, and endure drought well.

In the case of moorland plants there is an obvious reason why many of them, though not quite all (Sphagnum is ore exception) should rather thirst and grow slowly than pass large quantities of water through their tissues. The water contain hardly any potash or lime, and very little that can aid the growth of a plant. But it is probable that this is not the sole reason. Except where special defences are provided, it is dangerous for a plant which may be exposed to wind or low temperature to absorb much water.

(To be continuet.)

\section{INDIAN COALS AT THE IMPERIAL INSTITUTE.}

- HE Imperial Institute has been subjected to much adverse criticism. Its commercial collections, refreshment catering, fellow's' club, limelight lectures by eminent men, continental orchestras, library, exhibitions, journal, and commercial intel. ligence department have all in turn been disparaged. The scientific and technical department has alone escaped attack. There, in well-equipped laboratories, with an enthusiastic staft of experts, valuable research work on new products has been carried on quietly and continuously for some years past. it striking example of the value of the work done is afforded by

1 Examples are quoted by Warming, Lckrl. dt. Jkol. F'flantingeorraphic', p. 298 "Silit

$$
\text { NO. I } 503 \text {, VOL. } 58 \text { ] }
$$

the exhaustive report just published on the coal supply of India by Prof. Wyndham R. Iunstan. This report embodies the results of the examination of a large number of selected samples from the principal seams. Methodically arranged, well printed, and written in a style that is not too abstruse for the general reader, it is a model of what such a report should be.

The examination was undertaken at the instance of the Government of India. The results are shown in a tabular form, and the chief points in connection with the occurrence, dis tribution, production and character of Indian coal are summarised. Unlike the English and Welsh coals, the Indian coals are chiefly of Upper P'alreozoic and Lower Jurassic age. They are widely distributed, and only a small portion of the known coal area is as yet worked. The increase in coal pro. duction in India of late years is very remarkable, and, as the household consumption is inappreciable, practically the whole output is used for steamships, railways, and factories. The output for 1896 was as follows:-

\begin{tabular}{lrrrrr} 
Assam & $\ldots$ & $\ldots$ & $\ldots$ & $\ldots$ & \multicolumn{1}{c}{ Tons. } \\
Baluchistan $\ldots$ & $\ldots$ & $\ldots$ & $\ldots$ & 10,572 \\
Bengal & $\ldots$ & $\ldots$ & $\ldots$ & $\ldots$ & $3,037,920$ \\
Burna & $\ldots$ & $\ldots$ & $\ldots$ & $\ldots$ & 22,993 \\
Central India & $\ldots$ & $\ldots$ & $\ldots$ & 115,386 \\
Central Provinces $\ldots$ & $\ldots$ & $\ldots$ & 141,185 \\
Nizam's dominions & $\ldots$ & $\ldots$ & 262,681 \\
$\begin{array}{l}\text { Madras } \\
\text { P'unjal, }\end{array}$. $\ldots$ & $\ldots$ & $\ldots$ & $\ldots$ & 79,925 \\
\multicolumn{2}{c}{ Total } & $\ldots$ & $\ldots$ & $\ldots$ & $3,848,013$
\end{tabular}

The results of the examination of the various coals have been plotted in curves, and a table of previous analyses of Indian coal is also given. The coals vary greatly in composition and in quality. Most of them are quite suitable for ordinary purposes, whilst some of the samples from Bengal and Central India are of excellent quality, quite equal to that of many English or Welsh coals. Among the many samples described are two from Hyderabad, which are of fair quality. Neither of the samples, however, gave such good results as those recorded by Mr. Tookey in Mr. J. P. Kirkup's monograph on the Singareni coalfield, published in the T'ransactions of the Federated Institution of Yining Engineers in 1894 (vol. vi. pp. 42 I-448). This valuable memoir appears to have escaped Prof. Dunstan's notice in drawing up his useful list of works of importance in connection with Indian coal. The Bengal coal is that most largely mined, and a great deal of it is a serviceable steam-coal. Many samples cake well, and contain but little sulphur. The coke made from this coal appears, therefore, to be suitable for iron making. In view of the occurrence of rich deposits of iron and manganese ores in India, this is a matter of great importance, for, owing to difficulties connected with fuel supply, the records of iron manufacture in India have been disastrous. Attempts to manufacture steel in Southern India were made in 1818 , in 1830 , in 1833 and in 1853 , but in each case the want of suitable fuel was an unsurmountable difficulty. Charcoal was exclusively used; and in orcler to supply one blast-furnace it was necessary to clear no less than two acres of muderately heavy forest per day. For every ton of charcoal made, five tons of wood were consumed. The information contained in Prof. Dunstan's report shuuld therefore show that the difficulties in the way of creating an Indian iron inclustry presented by the fuel supply can easily be overcome. Indeed, the supply of coal is so enormous that this report should be the means of directing attention to the possibilities of many other branches of industrial enterprise.

BEXNETT II. BROUGiH.

\section{THE INTERNATIONAL AERONAUTICAL} CONFERENCE.

TIIF second meeting of the International Aeronautical Com. mittee (which was appointed by the Paris Meteorological Conference of 1896) was held at Strassburg, Germany, March 3 I to April 4, inclusive. Besides the P'resident, Prof. IIergesell of Strassburg, and the Secretary, .M. de Fonvielle of Paris, there were present the following members of the com. mittee : IIessrs. Cailletet and Besançon of Paris, Assmann and Berson of Berlin, Erk of Munich, Kykatcheff and Kowanko of

I By A. Lawrence Rotch. (Reprinted from the U.S. Monthly Weather Recieze for April.) 
St. Petersburg, and Rotch of Boston, U.S A. Regrets were sent to Messrs. Hermite and Violle, whom illness detained, and thanks were tendered to those governments and friends of science who proposed to search for André, a member of the committee. A number of physicists, meteorologists, and aeronauts were present as guests. The welcome of the German Government was extended by Von Schraut, Minister of Finance for Alsace-Loraine, who summarised the results achieved in exploring the atmosphere, and predicted a brilliant future. Prof. Windelband, Rector of the University of Strassburg, em. phasised the importance of these researches for the progress of humanity as well as for science. M. de Fonvielle replied for the Committee.

The discussion of the provisional programme was then begun, with the questions relating to the ballons sondes. It was agreed that the introduction of a mechanical ballast discharger was necessary, and that all precautions should be taken to prevent derangement of the instruments ; the stoppage of the clockwork was attributed to the contraction of the plates carrying the pivots, from the effect of great cold. As regards the calculation of the ascensional force of balloons and the influence of the temperature of the gas, it was resolved that-

For each unmanned ascent the weight of the aerostatic material and the ascensional force at the start should be measured, and during the whole voyage the true temperature of the gas should be recorded.

Since the study of the meteorological conditions of the air in a vertical line is important it was considered advisable, in certain cases, to limit the length of the voyage by emptying the balloon automatically.

The instrumental equipment of ballons sondes was first considered. M. Teisserenc de Bort presented a report on the determination of height by the barometer.

Drs. Assmann and Berson said that the usual methods gave considerable errors, and they recommended the calculation of the height by successive strata, applying a correction for the change of temperature of the lower stratum during the ascent. The Conference decided that-

All nations should adopt the same formula of reduction, whatever method might be chosen ultimately.

M. Teisserenc de Bort analysed the errors of the aneroid with respect to the mercurial barometer, but in regard to the latter it was pointed out by Dr. Berson that the mercurial column only represents the atmospheric pressure at the moment when the balloon has no vertical velocity. It was resolved that-

Simultaneous observations should be executed at the different stations, and that the instruments should be controlled by taking them in manned balloons. Besides this, the instruments ought to be interchanged among the different stations in as short a time as possible.

The determination of the temperature of the air in ballons sondes was introduced by a report of $\mathrm{M}$. Teisserenc de Bort. Dr. Hergesell remarked that the temperature of the air varied so rapidly that it was necessary to apply a correction-formula which he had developed in the Meteorologische Zeitschrift, December I897. M. Cailletet exhibited a thermometer of his invention, which had for its bulb a spiral silver tube soldered to a glass tube, both being filled with the liquid toluene. $\mathrm{He}$ stated that it acquired the surrounding temperature in fifteen seconds. M. Teisserenc de Bort exhibited a self. recording thermometer, having a thin blade of German silver fixed in a frame of Guillaume's invariable steel. This instrument takes the temperature of the air rapidly $\left(9^{\circ} \mathrm{F}\right.$. in fifteen seconds), and it is not affected by shocks. The ventilation in a balloon is secured by a fan driven by a weight on a wire, which falls 5000 feet in an hour and a half. Drs. Hergesell and Assmann described their attempts to construct a sensitive metallic thermometer, which the latter thought might be ventilated by the agitation of the air through a jet of liquid carbonic acid, but M. Cailletet pointed out that at low temperatures the tension of carbonic acid is too slight to produce ventilation. Dr. Berson remarked that in his high ascent, the upper clouds, at an altitude of 24,000 to 29,000 feet, radiated upon the instruments in the same way as does the surface of the earth at a moderate height. As a result of the discussion it was resolved-

(I) The rapidity of the thermometric variation is so great $\mathrm{n}$ ballons sondes that to record it thermometers must be emNO. I 503 , VOL. 58 ] ployed which have much less thermal inertia than those hitherto employed, and (2) an efficient ventilation of the thermometers is indispensable.

The testing of thermometers at temperatures below those to which they would be exposed in ballons sondes was advised, and Dr. Erk described the apparatus of Dr. Linde, of Munich, for the production of a considerable quantity of liquid air. This means of refrigeration enables temperatures lower than $200^{\circ} \mathrm{C}$. below zero to be obtained. The Conference recommended that-

Before the ascensions of ballons sondes the instruments be verified by varying the temperature and pressure under conditions similar to those to which they would be subjected in the atmosphere.

The equipment of manned balloons was next considered. Some remarks of Dr. Berson on the difficulty of reading a mercurial barometer, owing to the continual oscillations of the mercury, led to the following resolution :

During ascents, the mercurial barometer is the standard instrument for the comparison of aneroids, but for its observ. ations to be trustworthy the acceleration must be zero; it is evident that this condition is fulfilled when the trajectory traced by the self-recording aneroid is horizontal.

In consequence of the statement that it was possible to verify the instruments by reproducing the curves traced by them, the Conference advised that-

There should be reproduced in the laboratory, with the aid of pneumatic and refrigerating apparatus, similar curves to those traced by the barometer and thermometer during balloon. ascents.

Furthur discussion followed as to the methods of obtaining the height of the balloon. M. Cailletet described his apparatus for automatically photographing together, from time to time, the ground vertically below the balloon and the face of an aneroid barometer. From a map the route of the ballonn as well as its true altitude are determined; the pressure is deduced from the barometer, and thus the law connecting atmo. spheric pressure with altitude can be studied. Photographis have been taken from a balloon 7000 feet high, which was moving forty to sixty miles an hour. The accuracy of these measures was said to be within $\mathbf{I} / 25^{\circ}$ of the height. It is proposed to photograph a mercurial barometer in the same way. The Conference recommended the use of M. Cailletet's apparatus for both manned balloons and ballons sondes. The determination of the height by observations at the ground was brought to the attention of the Conference, and especially the "dromograph," invented by MM. Hermite and Besancon, for automatically registering the azimuths and angular altitudes observed, and the heliometer used by Dr. Kremser, of Berlin, for measuring the apparent diameter of the balloon.

Dr. Erk called attention to the fact that in the case of a large difference of temperature between the wet and dry bulbs of the aspiration psychrnmeter, the wet bulb always had in its immediate neighbourhood a warmer body, which is the interior cylinder surrounding it. The resulting error may be avoided by covering the interior cylinder with muslin, so that the dry bulb is protected by a cylinder having a temperature, $t$, and the wet bulb by a cylinder having a temperature, $t^{\prime}$. The Conference thought it necessary that -

The instrumental equipment of manned balloons should be uniform, so far as possible. A recommendation has been made in regard to the barometers; concerning thermometers, the opinion is expressed that the aspiration psychrometer placed at the proper distance of at least 5 feet from the basket is the only instrument which should be employed in manned ascents. Simultaneous comparisons with the sling thermometer are recommended.

Drs. Berson and Hergesell urged the importance of simultaneous ascents in the different countries when a centre of barometric depression existed over the European Continent. From a purely meteorological point of view the manned ascents have an importance which the ballons sondes do not, because the temperature of these high regions can have no influence on the meteorological elements near the surface of the earth. $M$. de Fonvielle, however, insisted upon the interest of deducing experimentally, from thermometric measures at a very great elevation, the temperature of the supra-atmospheric medium. 
He called attention to the possibility of choosing in this way between the kinetic theory of gases, which supposes a temperature of $273^{\circ} \mathrm{C}$. below zero, and Fourier's theory which assumes that the temperature of space above the atmosphere is near that of the minima observed in the polar regions of the earth.

Future international balloon ascensions were next considered. It was deemed advisable that-

For each ballon sonde an instrument should be provided to serve as a basis of comparison with perfected instruments whose construction may change from one ascent to another on account of the improvements which may be attempted.

It was announced that in the next international ascent of ballons sondes Austria, Italy and Belgium would participate, besides the countries which had already co-operated. This ascent was appointed for the beginning of June with certain stations of the international system to be chosen as starting points. The balloons should be as nearly as possible like those approved by the Conference, and the directors of the various meteorological systems were requested to institute observations on the days of the ascents according to the principles fixed by the President of the Committee. It was recommended that-

For the simultaneous study of the lower air strata, the observations from high stations be used, and especially those from kites and kite balloons.

After a presentation of various methods for effecting the safe landing and the recovery of ballons sondes, resolutions looking to these ends were adopted. Balloons may be protected against explosion caused by atmospheric electricity by covering their interior surface with a solution of potassium chlorate, which renders the fabric a conductor. For the measurement of atmospheric electricity the methods of Le Cadet, Börnstein and André are recommended, especially the former.

Mr. Rotch read the report which he had been requested to prepare an the use of kites at Blue Hill Observatory, U.S.A., to obtain meteorological observations. He showed the advantages which kites possess over balloons up to heights exceeding I0,000 feet, whenever there is wind.

A letter from the Chief of the Weather Bureau explained the proposed use of kites to obtain data for a daily synoptic weather chart over the United States at the height of a mile or more. M. Teisserenc de Bort is equipping a kite station at Trappes, near Paris, after the model of Blue Hill, and General Rykatcheff stated that an anemograph of his invention was being raised with Hargrave kites at St. Petersburg. The Conference recommended the use of the kite in meteorology, and expressed the wish that all central observatories should make such observations, which are of prime importance for meteorology. On account of the favourable position of Mount Cimone and Etna it is desirable that at the observatories on these mountains kites should be used in connection with the international balloon ascensions. The Conference expressed the desire that the chief observatories should be provided with the kite balloon of von Parseval and von Siegsfeld (see description hereafter) in order that there may be a certain number of permanent aerial stations, and following the idea of M. Tacchini it is hoped that kite balloons will be used in Italy on Mounts Viso and Etna, and also at the Military Park at Rome.

The following new members of the Committee were elected : M. Teisserenc de Bort and Prince Roland Bonaparte, of Paris, Prof. Hildebrandsson, of Upsala, Prof. Pernter and Lieut. Hinterstoisser, of Vienna, Captain Moedebeck, of Strassburg, and Lieut. von Siegsfeld, of Berlin. The next meeting was appointed for I900, at Paris, during the Universal Exposition.

The Committee had the opportunity of witnessing two trials of the captive kite balloon, invented by Lieuts. von Parseval and von Siegsfeld, and constructed by Riedinger, of Augsburg, at a cost of 1000 dols., for Prof. Hergesell and Captain Moedebeck. Although this form of balloon is used in the German army for reconnoitring, it was now employed for the first time to lift self-recording meteorological instruments. The cylindrical balloon is so attached to the cable that its upper end inclines towards the wind, which thus raises instead of depressing it, as in the case of captive spherical balloons. The wind enters an auxiliary envelope at the lower extremity and maintains the cylindrical form, notwithstanding any loss of gas. This wind bag also serves as a rudder, while lateral No. I 503 , vOL. 58$]$ wings prevent rotation about the longer axis. The Strassburg balloon has a diameter of 14.7 feet, a length of 55.7 feet, and a volume of 7770 cubic feet. The gas bag is varnished linen, and was filled with a mixture of hydrogen and coal gas. The weight of the balloon complete is $23^{\circ}$ pounds, and the steel cable holding it weighs 2 punds per Ioo feet. The azimuth, altitude, and traction of the cable are recorded by a dynamometer invented by Riedinger. The meteorological instruments are contained in a basket (with open ends, through which the wind blows, but covered elsewhere with nickeled paper as a protection against insolation), suspended some 40 feet below the balloon. The self-recording instruments were a barometer and thermometer of Richard and a Robinson anemometer recording electrically. Although the kind of gas employed was hardly sufficient to lift the unnecessarily heavy basket and its contents, weighing 80 pounds, yet the trials made in rainy and windy weather were fairly successful, and a height of about 1000 feet was reached. Without instruments the balloon had remained for several days above the city, and had withstood a gale.

The Committee also saw a hastily organised ascent of the ballon sonde, "Langenburg," which is a silk balloon of about I 4,000 cubic feet capacity. When filled with coal gas it had an initial ascensional force of about 440 pounds in excess of its own weight and that of the instruments, contained in a cylindrical basket, which was open at top and bottom for ventilation, and was also covered with nickeled paper. They comprised a barometer and thermometer of Richard, and the metallic thermometer of Teisserenc de Bort, which all recorded on smoked paper. Owing to the premature launch of the balloon the baliast was left behind, and the escape of gas, owing to the too rapid ascent, prevented a great height from being reached. The balloon rose at about $6 \mathrm{p} . \mathrm{m}$. with a velocity of nearly 23 feet per second, and disappeared in the strato-cumulus clouds in five minutes. It attained an altitude exceeding 6 miles, and fell about 60 miles south-east of Strassburg, where it was found the next day. Unfortunately the shock caused by the breaking loose of the balloon stopped the clocks of the thermographs and prevented records of temperature from being obtained.

An official account of this Conference will be published in the French and German languages, together with the special reports prepared by the experts.

\section{UNIVERSITY AND EDUCATIONAL INTELLIGENCE.}

AMONG the measures which received the Royal consent on Friday was the London University Commission Bill.

Mr. A. J. Herbertson, Lecturer on Geography in the Heriot-Watt College, Edinburgh, has taken the degree of Ph.D., multa cum laude, in the University of Freiburg, Baden, in the special subject of geography. The subject of his thesis was the mean monthly rainfall of the globe, illustrated by twelve original maps.

THE resident professorship of Physics and Mechanics in the Royal Agricultural College, Cirencester, has been filled up by the election of Mr. John Alexander Johnston. At Edinburgh Mr. Johnston was first medallist in advanced honours class of mathematics, and first medallist in advanced honours class of physics, and in 1894 he graduated M.A. with first class honours in mathematics and physical science, and afterwards obtained the Drummond scholarship for proficiency in physical science, as well as other open honours. At Pembroke College, Cambridge, he was awarded both minor and foundation scholarships, and graduated fourteenth wrangler in the mathe. matical tripos.

A special and valuable feature of the Museum of the Peabody Institute at Salem, Mass., is referred to by Mr. W. E. Hoyle in the course of a description of museums in the United States and Canada, contained in the report of the Manchester Museum, Owens College (1897-8). Mr. Hoyle mentions that at close intervals throughout the entire collection special coloured labels are displayed, calling attention, by title and shelf number, to books in the public library referring to the immediate group, so that a student or pupil from the public schools need only transcribe on a bit of paper a set of numbers and present it at the delivery window of the public library to be provided at once with the books on the special subject desired. 